\title{
Hilal dalam Perspektif Tafsir Al-Quran
}

\author{
Badrun Taman $^{1 *}$, Muthi'ah Hijriyati' ${ }^{2}$, Karis Lusdianto ${ }^{3}$, Abdulloh Hasan $^{4}$ \\ ${ }^{1}$ IAIN Bengkulu, ${ }^{2}$ IAIN Kediri, ${ }^{3}$ UIN Walisongo, ${ }^{4}$ IAIN Purwokerto \\ ${ }^{1 *}$ Email: badruntaman.ofc@gmail.com
}

\begin{abstract}
The difference in criteria of hilal because of differences in understanding the texts of the al-Quran talks about hilal. Then, this is important to determine the substance of hilal in those verses. This Substance of hilal can be reffered both in understanding verses of hilal and determining criteria of hilal. This research aims to study the explanation of the mufassirs about the substance of hilal and how the substance of the hilal in the perspective of the al-Quran interpretation. This research is qualitative-library research with hermeunethic and astronomical approach. The books of al-Quran interpretation as the primary data source.. The results showed the novelty about hilal. Hilal has six aspects, namely aspects of form, appearance, phase, time, place, and clarity of change. Hilal in the perspective of the al-Quran interpretation is a hilal that is soft like a thread, the phenomenon of its appearance can be observed (badawah al-hilal or zuhur al-hilal), in the sirar phase, on the first 2 nights after the mihaq phase, on the western horizon, with clear phase changes so as to make it easier for humans to determine time.
\end{abstract}

Keywords : Islamic Astronomi, Contemporary, Restaurant, Qibla.

\begin{abstract}
Abstrak
Perbedaan kriteria hilal dikarenakan perbedaan memahami ayat al-Quran tentang hilal. Maka dari itu penting untuk ditemukan hakikat makna hilal dalam ayat al-Quran tersebut. Substansi makna hilal ini bisa menjadi rujukan baik dalam hal memahami ayat hilal maupun penentuan kriteria hilal awal bulan. Penelitian ini bertujuan mengkaji penjelasan para mufassir tentang substansi makna hilal, dan bagaimana substansi hilal perspektif tafsir al-Quran. Jenis Penelitian ini adalah kualitatif-library research dengan pendekatan tafsir dan astronomi. Data primernya adalah kitab-kitab tafsir pada periode salaf, khalaf, dan kontemporer. Hasil penelitian menunjukkan hal baru tentang hilal, yaitu bahwa substansi hilal menurut para mufassir memiliki enam aspek, yaitu aspek bentuk, ketampakan, fase, waktu, tempat, dan kejelasan perubahan. Hilal perspektif tafsir al-Quran adalah hilal yang bentuknya lembut seperti benang, fenomena ketampakannya dapat teramati (badawah al-hilal atau zuhur al-hilal), pada fase sirar, pada 2 malam pertama setelah fase mihaq, di ufuk langit sebelah Barat, dengan perubahan fase yang jelas sehingga memberikan kemudahan bagi manusia dalam penentuan waktu.
\end{abstract}

\section{Kata Kunci : Ilmu Falak, Kontemporer, Rumah Makan, Kiblat.}

Artikel Info

Received:

16 Februari 2021

Revised:

23 Maret 2021

Accepted:

03 Mei 2021

Published:

08 Juni 2020 


\section{AL-MARSHAD: JURNAL ASTRONOMI ISLAM DAN ILMU-ILMU BERKAITAN \\ ISSN 2442-5729 (print) || ISSN 2598-2559 (online) \\ http://jurnal.umsu.ac.id/index.php/almarshad \\ DOI: //doi.org/10.30596/jam.v7i1.6404 || Vol. 7, No. 1 Juni 2021}

\section{A. Pendahuluan}

Hilal menjadi objek terpenting dalam kajian penentuan awal bulan di Kalender Islam (Hijriyah). Sebab ia merupakan tanda dimulainya bulan Qomariyah baru berikutnya. Pada saat terbenam Matahari di akhir tanggal 29 bulan Hijriyah, jika hilal sudah muncul, maka malam tersebut sudah masuk tanggal 1 bulan berikutnya. Namun jika hilal tidak muncul, malam itu adalah tanggal 30 dari bulan Hijriyah tersebut.

Kemunculan hilal ini pada mulanya diamati dengan melihatnya secara langsung tanpa menggunakan perhitungan sebelumnya.Seiring dengan perkembangan ilmu pengetahuan, peredaran bulan dapat dihitung melalui perhitungan matematis, sehingga posisi dan kedudukan bulan bisa diketahui meskipun tanpa diamati secara langsung. Posisi Bulan terhadap ufuk Bumi dan Matahari dapat diketahui secara presisi dari hasil perhitungan tersebut.

Seiring dengan ditemukannya sistem perhitungan peredaran dan kedudukan bulan terhadap Matahari dan Bumi, perbedaan pandangan terhadap penentuan awal bulan Hijriyah mulai muncul.Perbedaan terjadi pada mulanya pada aspek boleh tidaknya menggunakan perhitungan (hisab), karena belum diinformasikan pada teks-teks dalam
Nash, kemudian berkembang pada aspek kriteria posisi dan kedudukan bulan agar bisa disebut hilal.

Pada saat ini perbedaan kriteria posisi bulan tersebut dapat dikelompokkan menjadi tiga. Pertama, wujudul hilal, yakni jika posisi bulan sudah di atas ufuk setelah terbenam Matahari pada tanggal 29 bulan Hijriyah, maka hilal sudah dikatakan ada (wujud), tidak perduli berapapun ketinggiannya dari ufuk. Kedua, rukyatul hilal, yaitu posisi bulan sudah di atas ufuk setelah terbenam Matahari pada tanggal 29 bulan Hijriyah dan bisa dilihat pada saat diobservasi. Jika tidak bisa dilihat, meskipun sudah di atas ufuk, hari berikutnya belum masuk bulan baru. Ketiga, imkanur rukyat, yakni posisi bulan memiliki kemungkinan bisa dilihat jika cuaca normal dan bulan tidak terhalang. Kriteria ini menghendaki meskipun bulan tidak bisa dilihat, asalkan posisinya memungkinkan, maka malam itu sudah memasuki tanggal 1 bulan berikutnya. ${ }^{1}$

Perbedaan pilihan kriteria keadaan dan posisi bulan sehingga disebut hilal ini terjadi di antaranya karena perbedaan dalam memahami nash-nash al-Quran yang dijadikan sebagai landasan hukum penentuan awal bulan. Mesikpun hilal adalah fenomena yang menjadi kajian sains astronomi, ketika

${ }^{1}$ Abu Yazid Raisal, 'Berbagai Konsep Hilal Di Indonesia', Al-Marshad, 4.2 (2018), 151-53. 


\section{AL-MARSHAD: JURNAL ASTRONOMI ISLAM DAN ILMU-ILMU BERKAITAN \\ ISSN 2442-5729 (print) || ISSN 2598-2559 (online) \\ http://jurnal.umsu.ac.id/index.php/almarshad \\ DOI: //doi.org/10.30596/jam.v7i1.6404 || Vol. 7, No. 1 Juni 2021}

menjadi acuan awal bulan, maka ia juga sebagai objek kajian keislaman. Hal ini karena konsekuensi awal bulan berkaitan dengan penentuan waktu pelaksanaan ibadah dalam Islam.

Untuk itu, pilihan kriteria hilal tidak bisa berdasarkan kajian sains semata, namun juga harus mempertimbangkan pemahaman para ulama yang otoritatif dalam menafsirkan al-Quran, begitu juga sebaliknya. Namun sebelum ke pemahaman saintifik, objek studi keagamaan apapun terlebih dahulu harus dikaji dari aspek penjelasan para ulama terhadapnya. Hal ini tidak lain karena merekalah para pewaris Nabi, artinya ketika Nabi sudah tidak ada, merekalah yang menjadi referensi jawaban persoalan keagamaan.

Beberapa studi terkait penafsiran ayat hilal di antaranya adalah Qamarus Zaman ${ }^{2}$ yang mengkaji definisi dan kajian ayat hilal dari perspektif tafsir dan sains. Menurut penelitian ini Hilal merupakan tanda petunjuk atau penanda waktu dan merupakan satu kesatuan sistem waktu yang terdiri dari hari, bulan dan tahun. Sistem seperti ini menjadi bentuk kalender (almanak, taqwim) yang dipergunakan secara mudah untuk kepentingan umat manusia dalam

2 Qamarus Zaman, 'Memahami Makna Hilal Menurut Tafsir Al-Quran Dan Sains', Universum, 9.1 (2015).

${ }^{3}$ Zaman. pelaksanaan ibadah puasa, haji, waktu shalat, penentuan masa iddah dan perjanjian mualamah lainnya. ${ }^{3}$ Beberapa kitab tafsir yang dijadikan rujukan adalah Tafsir alJalalain, Tafsir al-Tabari, Tafsir al-Qurtubi, Tafsir Ibn Kasir, Tafsir al-Razi, dan Tafsir Fi Zilal al-Quran. Referensi kitab tafsir yang digunakan belum menggambarkan kontinyuitas perkembangan pemaknaan hilal dari masa dulu hingga sekarang.

Kemudian penelitian Uswatun Khazanah yang membandingkan penafsiran hilal antara al-Qurtubi dan Tantawi Jauhari. ${ }^{4}$ Menurutnya penafsiran hilal yang digunakan oleh imam al-Qurthubi dan imam Tantawi Jauhari tersebut sudah diaplikasikan oleh masyarakat dengan metode rukyat dan hisab. Metode rukyat telah di imbangi dengan metode hisab yang di gunakan oleh imam Tantawi Jauhari. Sedangkang metode hisab digunakan oleh imam al-Qurthubi. Perbadingan tersebut telah diaplikasikan dalam ormas-ormas di Indonesia antara NU dan Muhammadiyah. Penelitian ini juga belum menggambarkan perkembangan makna hilal dari perspektif tafsir klasik hingga modern.

Ketiga adalah penelitian Yuchbibun Nury Muhammad yang mengkaji Tafsir

\footnotetext{
${ }^{4}$ Uswatun Khazanah, Penafsiran Hilal Menurut Qurthubi Dan Tantawi Jauhari, Skripsi (UIN Sunan Gunung Jati, 2018).
} 


\section{AL-MARSHAD: JURNAL ASTRONOMI ISLAM DAN ILMU-ILMU BERKAITAN \\ ISSN 2442-5729 (print) || ISSN 2598-2559 (online) \\ http://jurnal.umsu.ac.id/index.php/almarshad \\ DOI: //doi.org/10.30596/jam.v7i1.6404 || Vol. 7, No. 1 Juni 2021}

Ayat-ayat Hilal Perspektif Kemenag RI dan LIPI. ${ }^{5}$ Penelitian ini menyimpulkan bahwa bahwa bulan memberikan beberapa manfaat bagi penduduk bumi sebagai planet induknya. Kemenag RI dan LIPI membagi manfaat bulan bagi kehidupan manusia di bumi terhadap 3 hal; 1) Bulan sebagai satelit bumi, 2) Bulan sebagai penggerak pasang surut air laut, 3) Bulan sebagai penentu waktu. Implementasi hasil penelitian ini adalah diperlukannya sebuah kriteria umum hilal sebagai pedoman penentuan awal bulan Hijriyah di Indonesia. Kriteria umum tersebut pastinya berupa kriteria yang mudah dalam hal pemahaman maupun praktek di lapangan. Sehingga dapat diterima oleh kalangan masyarakat umum di Indonesia. Hasil penelitian ini hanya mendeskripsikan hakikat hilal dalam perspektif tafsir kontemporer.

Meskipun sudah banyak kajian tafsir ayat hilal, namun kajian mereka belum begitu menampakkan perkembangan penafsiran ayat hilal dari masa salaf, khalaf, hingga kontemporer. $^{6}$

$$
\text { Adapun kajian yang lebih }
$$
komprehensif tentang tafsir ayat hilal dilakukan oleh Fahmi Fatwa, Alhamuddin, dan Putra Bagus Muhammad. Mereka

\footnotetext{
${ }^{5}$ Yuchbibun Nury Muhammad, Tafsir Ayat-Ayat Hilal Perspektif Kemenag RI Dan LIPI, Diploma th (Institut Pesantren KH. Abdul Chalim, 2020).

${ }^{6}$ Dalhari, 'Tafsir Modern Di Timur Tengah Abad 19 Dan 20', Mutawatir: Jurnal Keilmuan Tafsir Dan Hadis, 3.1 (2013), 66-67.
}

mengkaji hilal dari aspek penamaan dan perkembangannya menurut ulama mutaqaddimin (klasik) dan mu'ashirin (modern). ${ }^{7}$ Hasil kajian menunjukkan bahwa hilâl merupakan bagian dari fase-fase bulan yang tampak pada dua atau tiga malam di awal bulan dan di akhir bulan. Namun hilâl yang dijadikan rujukan dalam penentuan awal bulan kamariah adalah fase bulan sabit yang pertama kali tampak setelah bulan mati atau setelah terjadi konjungsi. Meskipun begitu, referensi yang digunakan hanya pada sedikit ulama khalaf seperti al-Tabari, Zamakhsyari, dan Fakhruddin al-Razi, dan ulama kontemporer seperti Wahbah al-Zuhaili. Mereka belum menyertakan diskusi hilal menurut ulama salaf.

Pertanyaan Penelitian ini adalah: 1) bagaimana penjelasan para mufassir salaf, khalaf, dan kontemporer terhadap ayat-ayat yang menjadi dalil hilal dalam penentuan awal bulan dan 2) bagaimana substansi hilal perspektif tafsir al-Quran. Hal ini penting dilakukan agar dapat didudukkan penafsiran

\footnotetext{
${ }^{7}$ Fahmi Fatwa Rosyadi Satria Hamdani. Alhamuddin Alhamuddin dan Putra Bagus Mochammad, 'Al-Hilal Fi Al-Quran: Tasmiyah Al-Hilal Wa Tatawwuruha Ind Ulama Al-Tafsir Al-Mutaqaddimin Wa AlMu'ashirin Ala Wajh Al-Maudlu'i', Jurnal Tsaqafah: Jurnal Peradaban Islam, 12.2 (2016), 409-24.
} 


\section{AL-MARSHAD: JURNAL ASTRONOMI ISLAM DAN ILMU-ILMU BERKAITAN \\ ISSN 2442-5729 (print) || ISSN 2598-2559 (online) \\ http://jurnal.umsu.ac.id/index.php/almarshad \\ DOI: //doi.org/10.30596/jam.v7i1.6404 || Vol. 7, No. 1 Juni 2021}

otoritatif $^{8}$ terkait hilal sebagai penanda awal bulan yang bisa dijadikan rujukan dan pertimbangan dalam memahami ayat-ayat kauniyah terkait fenomena hilal. Di samping itu, pemilihan kriteria hilal agar dilakukan berdasarkan argumentasi ilmiah bukan berdasarkan fanatisme kelompok ataupun pemahaman. Dari hasil penelitian ini diharapkan dapat diperoleh penjelasan substantif tentang hilal dalam pandangan para ulama ahli tafsir.

\section{B. Metode Penelitian}

1. Jenis Penelitian

Sesuai dengan karakteristiknya, jenis penelitian ini adalah kualitatif-library research, yaitu penelitian terhadap kitabkitab tafsir, buku-buku, dan tulisan-tulisan ilmiah yang membahas tentang konsep hilal.

2. Pendekatan Penelitian

Sesuai dengan tema yang dikaji, pendekatan dalam penelitian ini adalah pendekatan tafsir tematik dan astronomi. Pendekatan tafsir digunakan untuk mencari penjelasan terhadap makna hilal perspektif ulama tafsir, sedangkan pendekatan astronomi digunakan untuk mengharmonisasikan pandangan ulama tafsir dengan perspektif astronomi.

\section{Sumber Data}

Sumber data primer penelitian ini adalah kitab-kitab tafsir, dari tafsir masa ulama salaf seperti Tafsir al-Quran al-Adim Li Ibn Hatim dan Tanwir al-Miqbas Min Tafsir Ibn Abbas, tafsir masa ulama khalaf seperti Jami' al-Bayan Fi Ta'wil al-Quran karya al-Thabari dan Tafsir al-Maturidi: Ta'wilat Ahli al-Sunnah, dan tafsir masa ulama kontemporer seperti Tafsir alSya'rawy, dan Tafsir al-Wasit li al-Tantawi.

4. Teknik Pengumpulan Data

Penulis menggunakan Teknik dokumenter dalam menghimpun data penelitian. Aplikasi Teknik ini dalam penelitian adalah dengan menangkap secara utuh ide dasar sumber primer apa adanya, kemudian ide tersebut dikaji melalui perspektif metode penelitian.

\section{Teknik Pengolahan Data}

Editing, yaitu kegiatan yang dilakukan setelah peneliti selesai mengumpulkan data. Dalam pengolahan data editing ini penulis akan memeriksa ulang data yang telah diperoleh dalam pencarian data dari kitab-kitab tafsir tersebut.

Coding, yaitu data atau informasi yang didapatkan perlu dikelompokan terlebih dahulu dengan cara memberi kode pada setiap jawaban. Dalam pengolahan data

\footnotetext{
${ }^{8}$ Muhammad Amin, 'Kontribusi Tafsir Kontemporer Dalam Menjawab Persoalan Ummat', Jurnal Substantia, 15.1 (2013), 4.
} 


\section{AL-MARSHAD: JURNAL ASTRONOMI ISLAM DAN ILMU-ILMU BERKAITAN \\ ISSN 2442-5729 (print) || ISSN 2598-2559 (online) \\ http://jurnal.umsu.ac.id/index.php/almarshad \\ DOI: //doi.org/10.30596/jam.v7i1.6404 || Vol. 7, No. 1 Juni 2021}

coding ini penulis memperoleh data atau informasi yang valid tentang penjelasan hilal melalui jalan pemberian kode dalam setiap jawaban.

Tabulasi, yaitu membuat tabel-tabel yang berisikan data yang telah diberi kode sesuai dengan analisis yang dibutuhkan. Dalam pengolahan data tabulasi penulis akan menganalisis data dan menyimpulkan sesuai dengan rumusan masalah.

\section{Teknik Analisa Data}

Kedua pertanyaan penelitian ini akan dianalisa dengan metode deskriptif-analitiskomparatif. Aplikasi metode deskriptif dalam penelitian ini adalah untuk menggambarkan holistisitas konsep hilal perspektif tafsir alQuran, baik tafsir ulama salaf, tafsir ulama khalaf, dan tafsir ulama kontemporer. Sedangkan metode analitis digunakan untuk melacak lebih jauh hal-hal yang berhubungan dengan penafsiran ayat hilal meliputi berbagai aspek yang melingkupi hilal. Adapun metode komparatif berfungsi untuk membandingkan pandangan dan pendapat para mufassir terkait hilal dalam rangka kompromisasi dan tarjih hakikat substansi hilal. sumber data primernya adalah kitabkitab tafsir.

\section{B. Hasil Dan Pembahasan}

\section{Inventarisasi Ayat-Ayat Hilal}

Pada bagian ini penulis akan mengumpulkan tiga tipe Ayat al-Quran, yaitu ayat yang menyebutkan secara eksplisit kata hilal atau derivasinya, ayat yang berkaitan dengan hilal namun dalam teks tidak tertulis kata tersebut, dan ayat tentang penentuan awal bulan. Yang pertama berfungsi sebagai sumber pencarian data hakikat hilal dan yang kedua berperan dalam memberikan kelengkapan informasi tentang hal-hal terkait hilal. Adapun ayat ketiga dikaji untuk mengetahui hubungan hilal dengan penentuan awal bulan.

Ayat yang menyebutkan secara eksplisit kata hilal adalah al-Baqarah ayat 189.

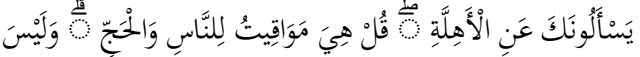

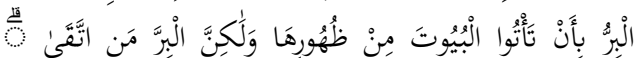

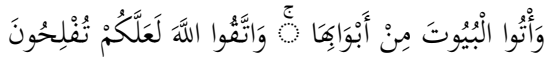

"mereka bertanya kepadamu tentang bulan sabit. Katakanlah: "Bulan sabit itu adalah tanda-tanda waktu bagi manusia dan (bagi ibadat) haji; dan bukanlah kebajikan memasuki rumah-rumah dari belakangnya, akan tetapi kebajikan itu ialah kebajikan orang yang bertakwa; dan masuklah ke rumah-rumah itu dari pintu-pintunya; dan bertakwalah kepada Allah agar kamu beruntung".

$$
\text { Secara ijmali, ayat ini }
$$
menginformasikan dialog antara para sahabat dengan Nabi Muhammad saw tentang hikmah di balik fenomena perubahan bentuk bulan. Kemudian Allah memberikan wahyu agar Nabi menyampaikan bahwa hikmahnya adalah sebagai acuan waktu bagi kegiatan- 


\section{AL-MARSHAD: JURNAL ASTRONOMI ISLAM DAN ILMU-ILMU BERKAITAN \\ ISSN 2442-5729 (print) || ISSN 2598-2559 (online) \\ http://jurnal.umsu.ac.id/index.php/almarshad \\ DOI: //doi.org/10.30596/jam.v7i1.6404 || Vol. 7, No. 1 Juni 2021}

kegiatan manusia, seperti puasa, berbuka, masa iddah wanita, masa tempo hutang, dan ibadah haji. ${ }^{9}$

Perubahan fase-fase bulan di atas juga disinggung dalam surat Yasin ayat 39, yaitu:

$$
\text { والقمر قدرناه منازل حتى عاد كالعرجون القديم }
$$

"dan telah Kami tetapkan bagi bulan manzilah-manzilah, sehingga (setelah Dia sampai ke manzilah yang terakhir) Kembalilah Dia sebagai bentuk tandan yang tua.

Ayat ini menginformasikan bahwa bulan-bulan itu pada Awal bulan, kecil berbentuk sabit, kemudian sesudah menempati manzilah-manzilah, Dia menjadi purnama, kemudian pada manzilah terakhir di akhir bulan seperti benang yang nampak sebagaimana tandan kering yang melengkung. ${ }^{10}$

$$
\text { Informasi tentang manzilah }
$$
perjalanan bulan juga tertera pada surat Yunus ayat 5, yaitu:

$$
\text { هو الذي جعل الشمس ضياء والقمر نورا وقدره منازل لتعلموا لقات السنين والحساب جعا خلق الله ذلك الا بالخق ج يفصل }
$$

Dia-lah yang menjadikan matahari bersinar dan bulan bercahaya dan ditetapkan-Nya

9 Al-Qism al-Ilmi Bi Muassasah al-Durar alSaniyyah, Al-Tafsir Al-Muharrar Li Al-Quran AlKarim (Arab Saudi: al-Durar al-Saniyyah, 2015).

${ }^{10}$ Abu al-Hasan Muqatil ibn Sulaiman, Tafsir Muqatil Ibn Sulaiman (Beirut: Dar Ihya al-Turas, 1423). manzilah-manzilah (tempat-tempat) bagi perjalanan bulan itu, supaya kamu mengetahui bilangan tahun dan perhitungan (waktu). Allah tidak menciptakan yang demikian itu melainkan dengan hak. Dia menjelaskan tanda-tanda (kebesaran-Nya) kepada orang-orang yang mengetahui.

Dari ayat ini dapat dipahami bahwa manzilah-manzilah bulan tersebut diciptakan Allah sebagai acuan manusia untuk mengetahui bilangan tahun dan perhitungan waktu. Hal ini karena berakhirnya bulan dan tahun dapat diketahui dengan fenomena hilal. ${ }^{11}$ Kemudian keterkaitan manzilah bulan dengan perhitungan juga dikuatkan dalam surat al-An'am ayat 96, yaitu:

$$
\text { ذالق الإصباح وجعل اليل سكنا والشمس والقمر حسبانا ج }
$$

Dia menyingsingkan pagi dan menjadikan malam untuk beristirahat, dan (menjadikan) matahari dan bulan untuk perhitungan. Itulah ketentuan Allah yang Maha Perkasa lagi Maha mengetahui

\section{Informasi tentanag keterkaitan} manzilah bulan dengan perhitungan tertuang dalam redaksi wa al-syams wa al-qamar husbana. Dalam tafsir al-Razi, menurut Ibn Abbas, maksud redaksi tersebut adalah bulan dan matahari dijadikan Allah sebagai acuan

11 Muhammad Ibn Jarir Al-Tabari, Jami' AlBayan Fi Ta'wil Al-Quran (Beirut: Muassasah alRisalah, 2000). 


\section{AL-MARSHAD: JURNAL ASTRONOMI ISLAM DAN ILMU-ILMU BERKAITAN \\ ISSN 2442-5729 (print) || ISSN 2598-2559 (online) \\ http://jurnal.umsu.ac.id/index.php/almarshad \\ DOI: //doi.org/10.30596/jam.v7i1.6404 || Vol. 7, No. 1 Juni 2021}

perhitungan jumlah hari, bulan, dan tahun.

Sedangkan menurut Qatadah, ia bermakna keduanya beredar dalam sistem hisab (perhitungan). ${ }^{12}$

\section{Hilal dalam Kajian Tafsir Ulama Salaf}

Ulama salaf yang dimaksud adalah ulama genarasi Nabi, Sahabat, Tabi'in, dan Tabi'it Tabi'in. Adapun kurun waktu generasi tersebut adalah sebelum tahun 300 Hijriyah. Beberapa Ulama Tafsir pada masa Sahabat antara lain Abu Bakar al-Siddiq, Umar Ibn al-Khattab, Usman Ibn Affan, Ali Ibn Abi Thalib, Abdullah Ibn Abbas, Abdullah Ibn Mas'ud, Ubay ibn Ka'ab, Zaid ibn Sabit, Abu Musa al-Asyari, dan Abdullah Ibn Zubair. Karena tafsir pada masa sahabat belum dibukukan dan masih dalam bentuk hadis, maka usaha mencari informasi tentang hilal dengan penelusuran hadis-hadis yang berkaitan. Informasi juga digali dari Kitab yang menghimpun tafsir ibn Abbas yaitu Tanwir al-Miqbas, meskipun tidak dibuat pada masa sahabat.

Dalam kitab tafsir tanwir al-Miqbas, dijelaskan bahwa yang dipertanyakan sahabat tentang al-ahillah (hilal-hilal) dalam surat alBaqarah ayat 189 adalah ziyadah li ahillah wa

${ }^{12}$ Ibn Abi Hatim al-Razi, Tafsir Al-Quran AlAdim Li Ibn Hatim (Arab Saudi: Maktabah Nazar Mustafa al-Baz, 1419).

${ }^{13}$ Al-Fairuzzabadi, Tanwir Al-MiqbasMin Tafsir Ibn Abbas (Beirut: Dar al-Kutub al-Ilmiyyah). nuqsaniha, bertambah dan berkurangnya hilal. ${ }^{13}$ Definisi hilal tidak dijelaskan di dalamnya, namun dari penjelasan tentang perubahan bentuk hilal yang berkurang dan bertambah ini mengindikasikan fenomena penampakan hilal yang bisa diobservasi secara langsung dari Bumi.

Pada masa Tabiin, informasi tafsir tentang hilal ditelusuri pada karya-karya mufassir pada masa itu di antaranya Tafsir Mujahid.Namun ketika menjelaskan ayat tentang hilal, al-Baqarah ayat 189, kitab ini hanya menyinggung poin berikutnya dari ayat tersebut tanpa menjelaskan poin tentang hilal, ${ }^{14}$ begitu juga dengan tafsir surat Yasin ayat 39 .

Berbeda dengan masa Tabi'in, data penafsiran tentang ayat hilal di atas banyak ditemukan penjelasannya di kitab-kitab pada masa Tabi'i al-Tabi'in. Di antaranya dalam Tafsir Muqatil Ibn Sulaiman (w. $150 \mathrm{H}$ ) dijelaskan bahwa al-ahillah yang dimaksud berkaitan dengan fenomena perubahan bentuk bulan dari yabdu misla al-khait, tampak seperti benang, hingga menjadi penuh dan sempurna, kemudian terus berkurang hingga kembali sebagaimana semula. ${ }^{15}$

Bentuk terakhir dari fase bulan

\footnotetext{
${ }^{14}$ Abu al-Hajjaj Mujahid Ibn Jabr, Tafsir Mujahid (Mesir: Dar al-Fikr al-Islami, 1989).

15 Abu al-Hasan Muqatil Ibn Sulaiman, Tafsir Muqatil Ibn Sulaiman (Beirut: Dar Ihya al-Turas, 1423).
} 


\section{AL-MARSHAD: JURNAL ASTRONOMI ISLAM DAN ILMU-ILMU BERKAITAN \\ ISSN 2442-5729 (print) || ISSN 2598-2559 (online) \\ http://jurnal.umsu.ac.id/index.php/almarshad \\ DOI: //doi.org/10.30596/jam.v7i1.6404 || Vol. 7, No. 1 Juni 2021}

tersebut disebutkan dalam surat yasin ayat 39 seperti al-'urjunal-Qadim, yang ditafsirkan dengan al-'Azaq al-Yabis al-Manhiy alQadim, tandan tua kering yang melengkung. Yang dimaksud al-'azaq adalah 'izq alnakhlah, yaitu tandan kurma sebagaimana dijelaskan di tafsir Abd al-Razzaq (w. 211). ${ }^{16}$ Hal ini diperjelas oleh Yahya Ibn Salam (w. $200 \mathrm{H}$ ) bahwa bentuknya seperti 'unuq alnakhlah al-yabis, punggung tandan kurma kering ketika menjadi hilal. ${ }^{17}$ Hingga penjelasan ini dipahami bahwa fenomena hilal merupakan fenomena bida'ah(kenampakan) yang bisa diamati dari Bumi.

Mengenai Fungsi hilal sebagai penanda waktu diutarakan dengan tegas oleh Imam al-Syafii (w. 204) dalam tafsirnya bahwa laa tauqita illa bi al-ahillah, tiada menandai waktu kecuali dengan hilal-hilal. Menurutnya cara penentuan waktu dengan hilal inilah yang diajarkan Allah untuk penanda waktu umat Islam. Bahkan ia menandaskan bahwa siapa pun yang menandai waktu dengan selain hilal, maka ia menentukan waktu dengan selain yang diajarkan Allah. ${ }^{18}$

Penjelasan hilal oleh para Mufassir ulama salaf memang tidak banyak ditemukan,

\footnotetext{
16 Abd al-Razzaq al-San'ani, Tafsir Abd AlRazzaq (Beirut: Dar al-Kutub al-Ilmiyyah, 1419).

17 Yahya Ibn Salam, Tafsir Yahya Ibn Salam (Beirut: Dar al-Kutub al-'ilmiyyah, 2004).
}

namun dari beberapa tafsir di atas bisa diambil karakteristik hilal yang digunakan sebagai penentu waktu bagi manusia. Beberapa karakteristik tersebut dapat dilihat dalam Tabel 1. berikut:

Tabel 1. Karakteristik Hilal Perspektif Tafsir Ulama Salaf

\begin{tabular}{|c|c|c|c|}
\hline $\begin{array}{l}\mathbf{N} \\
\mathbf{0}\end{array}$ & Kriteria & $\begin{array}{l}\text { Karakteris } \\
\text { tik }\end{array}$ & $\begin{array}{l}\text { Keterang } \\
\text { an }\end{array}$ \\
\hline 1 & Bentuk & $\begin{array}{l}\text { Misla al- } \\
\text { khait }\end{array}$ & $\begin{array}{l}\text { Tipis } \\
\text { seperti } \\
\text { benang }\end{array}$ \\
\hline 2 & $\begin{array}{l}\text { Penampak } \\
\text { an }\end{array}$ & yabdu & $\begin{array}{l}\text { Tampak/b } \\
\text { isa } \\
\text { teramati }\end{array}$ \\
\hline
\end{tabular}

Dari Tabel 1. di atas dapat dirumuskan karakteristik hilal menurut para mufassir salaf adalah yabdu dan misla al-khait. Yabdu menghendaki hilal sebagai fenomena astronomi yang bisa teramati sedangkan misla al-khait menunjukkan bahwa penampakan hilal adalah sangat tipis seperti benang.

\section{Hilal dalam Kajian Tafsir Ulama Khalaf}

Penjelasan tentang hilal oleh para mufassir yang hidup setelah masa Tabi'i alTabi'in mulai mengalami perkembangan seiring dengan perkembangan metode dalam menafsirkan ayat al-Quran. Al-Tabari (w.

${ }^{18}$ Imam Al-Syafii, Tafsir Al-Imam Al-Syafi' $i$ (Arab Saudi: Dar al-Tadammuriyyah, 2006). 


\section{AL-MARSHAD: JURNAL ASTRONOMI ISLAM DAN ILMU-ILMU BERKAITAN \\ ISSN 2442-5729 (print) || ISSN 2598-2559 (online) \\ http://jurnal.umsu.ac.id/index.php/almarshad \\ DOI: //doi.org/10.30596/jam.v7i1.6404 || Vol. 7, No. 1 Juni 2021}

310) misalnya, lebih rinci dalam menjelaskan perubahan al-ahillah yang dimaksud surat alBaqarah ayat 189, yakni perubahan dari fase mihaq, sirar, tamam, dan istiwa'.

Al-Tabari juga menjelaskan kenapa hal ini dipertanyakan kepada Rasulullah saw, yaitu karena fenomena penampakan bulan berbeda dengan penampakan Matahari. Jika Matahari selalu tampak bulat sepanjang hari, bulan, dan tahun, maka Bulan selalu berubahubah bentuknya. ${ }^{19}$ Pernyataan al-Tabari ini senada dengan yang diutarakan al-Maturidi (w. 333) dalam kitab tafsirnya. Namun alMaturidi menambahkan bahwa Allah menjadikan hilal sebagai penentuan waktu dalam rangka mempermudah manusia, sebab menentukan tahun dan waktu dengan metode hari lebih berat perhitungannya. ${ }^{20}$

Dari fase-fase tersebut, hilal berada pada fase sirar. Dari segi bahasa sirar berarti rahasia atau samar. Hal ini mengindikasikan bahwa fenomena penampakan hilal adalah penampakan bentuk yang samar atau tidak begitu jelas sebab tipisnya hilal yang menyerupai benang.

Berkaitan dengan fase al-urjun alqadim dalam surat Yasin ayat 39, baik alTabari, al-Maturidi, dan para mufassir

${ }^{19}$ Ibn Jarir al-Tabari, Jami' Al-Bayan Fi Ta'wil Al-Quran (Beirut: Muassasah al-Risalah, 2000).

${ }^{20}$ Abu Mansur al-Maturidi, Tafsir Al-Maturidi: Ta'wilat Ahli Al-Sunnah (Beirut: Dar al-Kutub alIlmiyyah, 2005). lainnya sepakat dengan maksud penyerupaan fase-fase bulan dengan fase-fase tandan kurma yang sudah tua. Dalam hal fase atau manzilah, al-Maturidi menjelaskan bahwa baik Matahari dan Bulan memiliki manzilah yang keduanya teramati memiliki perubahan keadaan. Perbedaannya ada dalam jenis perubahannya. Jika bulan perubahan dalam bentuknya, sedangkan Matahari hanya perubahan dalam waktu peredarannya. Bulan terbit dan tenggelam setiap hari dalam bentuk yang berubah, sedangkan Matahari terbit dan tenggelam setiap harinya dalam bentuk yang tidak berubah. ${ }^{21}$

Penjelasan tambahan tentang hilal juga terdapat dalam tafsir al-Samarqandi (w.373) . Ia menjelaskan makna secara bahasa dari al-ahillah bahwa ia bentuk jamak dari hilal yang berarti meninggikan suara. Hal ini karena manusia meneriakkan suara mereka ketika melihat hilal. ${ }^{22}$ Adapun identifikasi hilal yang disebutkan dalam kitab ini diwakili oleh pencantuman sabab nuzul ayat, bahwa ada dua sahabat, yaitu Muaz ibn Jabal dan Sa'labah ibn Unmah al-Ansori, menanyakan perihal perubahan penampakan bulan, dengan redaksi sebagai berikut:

$$
\text { يا رسول الله ما بال الهلال يبدو فيطلع دقيقا مثل الخيط، ثم }
$$

21 Ibn Makhluf al-Sa'alabi, Al-Jawahir AlHissan Fi Tafsir Al-Quran.

${ }^{22}$ Abu al-Hasan Ali al-Mawawrdi, Al-Nukt Wa Al-Uyun: Tafsir Al-Mawardi (Beirut: Dar al-Kutub alIlmiyyah). 


\section{AL-MARSHAD: JURNAL ASTRONOMI ISLAM DAN ILMU-ILMU BERKAITAN ISSN 2442-5729 (print) || ISSN 2598-2559 (online) \\ http://jurnal.umsu.ac.id/index.php/almarshad DOI: //doi.org/10.30596/jam.v7i1.6404 || Vol. 7, No. 1 Juni 2021}

يزيد حتى يعظم ويستوي ويستدير ثم ينقص؟

Indikasi penampakan dalam redaksi di atas menggunakan kata yabdu yang artinya nampak dalam pengamatan. Setelah nampak kemudian hilal yattali' $u$,muncul atau terbit, dalam keadaan tampak tipis seperti benang. Dari sini dapat dipahami bahwa hilal bisa dikatakan (tulu') terbit jika sudah memenuhi kriteria yabdu yaitu tampak dari pengamatan di Bumi. ${ }^{23}$

Al-Sa'labi (w. 427) mendefinisikan hilal pada al-Baqarah ayat 189 secara bahasa yang berbeda dengan definisi al-Samarqandi. Ia menjelaskan bahwa disebut hilal karena orang-orang mengucapkan tahlil dengan zikir kepada Allah ketika melihatnya. Adapun sabab nuzul dari ayat tersebut semakna dengan yang disebutkan al-Samarqandi namun memiliki redaksi yang berbeda. Redaksi sabab nuzul tersebut sebagai berikut: ${ }^{24}$

$$
\begin{aligned}
& \text { يا رسول الله ما بال الهلال يبدو دقيقا مثل الخيط، ثم يزيد حتى }
\end{aligned}
$$

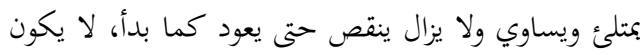

$$
\begin{aligned}
& \text { على حالة واحدة؟ }
\end{aligned}
$$

Redaksi sabab nuzul ini tidak menyebutkan kata yattali'u sebagaimana yang digunakan oleh al-Samarqandi. Namun identifikasi fenomena hilal masih senada

${ }^{23}$ Abu al-Lais al-Samarqandi, Bahr Al-Ulum.

${ }^{24}$ Abu Ishaq Ahmad Ibn Ibrahim al-Sa'labi, $A l$ Kasyf Wa Al-Bayan 'An Tafsir Al-Quran (Arab Saudi: Dar al-Tafsir, 2015). dengan al-Samarqandi dengan mengacu kepada kata yabdu sebagai indikasi penampakan hilal.

Berkenaan dengan perumpamaan hilal dengan al-urjun al-qadimdalam Yasin ayat 39, al-Sa'labi sependapat dengan ulama tafsir lainnya. Namun tentang manzilah, ia menafsirkan berbeda. Menurutnya bulan memiliki 28 manzilah. Setiap malam bulan menduduki salah satu dari 28 manzilah tersebut. ${ }^{25}$ Penjelasan al-Sa'labi ini senada dengan penjelasan al-Mawardi (w. $450 \mathrm{H}$ ) ketika menyebutkan pendapat kedua tentang tafsir manazil. Menurut al-Mawardi, ada dua pendapat tentang manazil, pertama, bulan setiap malam selalu menempati tempatnya menetap dan di sana ia tampak mengalami perubahan. Kedua, bulan setiap malam terbit pada manzilah tertentu hingga pada seluruh manzilah dalam satu bulan. ${ }^{26}$

Lebih lanjut tentang hilal, menarik untuk diperhatikan penjelasan atau tafsir dari Abu al-Hasan al-Wahidy (w.468 H ) yang memberikan definisi hilal sebagai gurrah alqamar (cahaya bulan) ketika mereka melihatnya. Dari sini bisa dipahami bahwa hilal merupakan fenomena cahaya bulan yang teramati. Al-Wahidiy juga mengutip pendapat bahwa bulan disebut dengan hilal 


\section{AL-MARSHAD: JURNAL ASTRONOMI ISLAM DAN ILMU-ILMU BERKAITAN \\ ISSN 2442-5729 (print) || ISSN 2598-2559 (online) \\ http://jurnal.umsu.ac.id/index.php/almarshad \\ DOI: //doi.org/10.30596/jam.v7i1.6404 || Vol. 7, No. 1 Juni 2021}

pada dua malam pertama dan dua malam terakhir. Sedangkan di antara dua masa itu disebut qamar. $^{27}$

Selain definisi al-Wahidy di atas, penting juga ditelaah definisi hilal Abu Mudaffar al-Sam'any (w. 489 H). Ia mendefinisikan hilal sebagai ism li al-qamar awwalu ma yabdu daqiqan, sebutan untuk bagian bulan yang tampak tipis pada kali pertama. Yang menjadi poin penting dari pengertian ini adalah kata $y a b d u$, yang berarti tampak. ${ }^{28}$ Adapun masa hilal disebut hilal adalah selama dua hari, meskipun ada yang bependapat bahwa bulan disebut hilal selama tiga hari. Hal ini sebagaimana diterangkan dalam garaib al-tafsir wa 'ajaib al-ta'wil karya Abu al-Qasim Burhanuddin al-karmani (w. $505 \mathrm{H}) .{ }^{29}$

Kemudian, penjelasan yang komprehensif tentang ayat hilal ini kiranya dapat ditemukan dalam kitab Mafatih al-gaib karya fakhruddin al-Razi (w.606 H). Pertama, al-Razi memberikan definisi hilal dengan awwalu hal al-qamar hina yarahu al-nas, yaitu keadaan pertama bulan ketika dilihat oleh manusia. Kedua, ia juga menyebutkan bahwa bulan disebut hilal pada dua malam pertama sebagaimana pendapat abu al-

${ }^{27}$ Abu al-Hasan al-Wahidy, Al-Tafsir Al-Basit (Arab Saudi: Jami'ah Imam Muhammad Ibn Saud alIslamiyah, 1430).

28 Abu al-Mudaffar al-Sam'any, Tafsir AlQuran (Riyad: Dar al-Watan, 1997).
Haisam. Ketiga, ia menjelaskan bahwa zaman yang dijadikan Allah ada 4, yaitu tahun, bulan, hari, dan jam. Zaman yang berkaitan dengan hilal adalah syahr (bulan). Syahr didefinisikan sebagai peredaran qamar (bulan) pada lintasannya secara khusus. ${ }^{30}$

Berdasarkan tafsir-tafsir di atas, terdapat beberapa informasi terkait karakteristik hilal yang diakomodir. Karakteristik hilal dalam tafsir-tafsir ulama khalaf dapat dilihiat dalam Tabel 2. berikut:

Tabel 2. Karakteristik Hilal Perspektif Tafsir Ulama Khalaf

\begin{tabular}{|c|c|c|c|}
\hline $\mathbf{N}$ & $\begin{array}{l}\text { Kriteri } \\
\text { a }\end{array}$ & $\begin{array}{l}\text { Karakterist } \\
\text { ik }\end{array}$ & $\begin{array}{l}\text { Keteranga } \\
\text { n }\end{array}$ \\
\hline 1 & Bentuk & $\begin{array}{l}\text { Misla al- } \\
\text { khait }\end{array}$ & $\begin{array}{l}\text { seperti } \\
\text { benang }\end{array}$ \\
\hline & & Daqiqan & Tipis \\
\hline 2 & Fase & Sirar & Samar \\
\hline 3 & $\begin{array}{l}\text { Ketam } \\
\text { pakan }\end{array}$ & $\begin{array}{l}\text { Yabdu } \\
\text { Yabdu Fa } \\
\text { Yattali'u } \\
\text { Awwalu Ma } \\
\text { Yabdu } \\
\text { Awwalu al- } \\
\text { Qamar Yura } \\
\text { Ghurrah al- } \\
\text { Qamar Yura }\end{array}$ & $\begin{array}{l}\text { Tampak/bi } \\
\text { sa teramati } \\
\text { Tampak } \\
\text { lalu terbit } \\
\text { Awalnya } \\
\text { bulan yang } \\
\text { tampak } \\
\text { Awalnya } \\
\text { bulan yang } \\
\text { terlihat } \\
\text { Guratan } \\
\text { cahaya } \\
\text { bulan yang } \\
\text { terlihat }\end{array}$ \\
\hline 4 & Waktu & $\begin{array}{l}2 \quad \text { malam } \\
\text { pertama } \\
3 \quad \text { malam } \\
\text { pertama }\end{array}$ & \\
\hline
\end{tabular}

29 Abu al-Qasim Burhanuddin al-Karmany, Garaib Al-Tafsir Wa 'Ajaib Al-Ta'Wil (Beirut: Dar alQiblah li al-Saqafah).

30 Fakhruddin al-Razy, Mafatih Al-Gaib (Beirut: Dar Ihya al-Turas, 1420). 


\section{AL-MARSHAD: JURNAL ASTRONOMI ISLAM DAN ILMU-ILMU BERKAITAN \\ ISSN 2442-5729 (print) || ISSN 2598-2559 (online) \\ http://jurnal.umsu.ac.id/index.php/almarshad \\ DOI: //doi.org/10.30596/jam.v7i1.6404 || Vol. 7, No. 1 Juni 2021}

Tabel 2. di atas menggambarkan berbagai redaksi terkait karakteristik hilal. Hilal memiliki bentuk yang tipis (daqiq) seperti benang (misl al-khait). Ia muncul (yattali' $u$ ) pada fase sirar (samar) di 2 atau 3 malam pertama setelah fase mihaq (bulan mati).Pada fase itu, hilal merupakan awalnya bulan yang tampak (yabdu) dan terlihat (yura) dengan penampakan guratan cahaya bulan (ghurrah al-qamar).

\section{Hilal dalam Kajian Tafsir Ulama Kontemporer}

Penjelasan tentang ayat hilal di karyakarya tafsir kontemporer tidak jauh beda dengan tafsir pada masa ulama khalaf dan ulama salaf. Beberapa kesamaan tersebut antara lain pada aspek definisi hilal sebagai qamar di dua malam pertama dan hikmah fenomena hilal sebagai penentu waktu. Kitabkitab tafsir tersebut antara lain tafsir karya alMaragi (w. 1371 H) ${ }^{31}$ dan Ibn Asyur (w.1393 H). ${ }^{32}$

Adapun tafsir yang lebih mendalam tentang asal-usul hilal dituangkan dalam karya al-Sya'rawi. Ia menjelaskan bahwa fenomena hilal berhubungan dengan posisi Matahari, Bumi, dan Bulan. Matahari memiliki ukuran 1,25 juta kali dari Bumi, dan

\footnotetext{
31 Ahmad ibn Mustafa al-Maragi, Tafsir AlMaragi (Mesir: Matba'ah Mustafa al-Halabi, 1946).

${ }^{32}$ Ibn Asyur, Al-Tahrir Wa Al-Tanwir (Tunis: al-Dar al-Tunisiah, 1984).
}

Bulan lebih kecil dari Bumi. Ketika posisi Bumi berada di antara Matahari dan bulan, maka Bumi menghalangi Bulan dari mendapatkan pantulan sinar Matahari. Besar bagian Bulan yang terhalang oleh Bumi dari Matahari itu sesuai dengan kadar luas busur Bumi yang menghalanginya.

$$
\text { Al-Sya'rawi (w. } 1418 \text { H) juga }
$$

menegaskan bahwa wujud Bulan sebenarnya tetap, namun ketika di antara Bulan dan Matahari terdapat bagian dari Bumi, maka ia terhalang dari sinar Matahari. Cahaya yang sampai ke bulan akan meluas ketika Bumi menjauh dari Bulan, dan bulan akan tampak sempurna pada saat Bumi pada p/osisi paling jauh dari Bulan. Cahaya yang sampai ke Bulan akan menyempit jika Bumi mendekat kembali dan menutupi Bulan dari mendapat Sinar Matahari. ${ }^{33}$

Adapun alasan Allah tidak memilih matahari melainkan hilal sebagai penentu waktu oleh Sayyid Tantawi dijelaskan karena faktor kemudahan dalam menentukan dimulai dan diakhirinya syahr (bulan). Bulan -bulan yang berbasis hilal dapat diketahui masuknya awal bulan dengan melihat hilal dan berakhirnya bulan dengan fenomena bulan mati (mihaq). Hal ini dapat dilakukan baik oleh orang khusus maupun orang umum.

33 Al-Syay'rawy, Tafsir Al-Sya'rawy (Mesir: Akhbar al-Yaum, 1997). 


\section{AL-MARSHAD: JURNAL ASTRONOMI ISLAM DAN ILMU-ILMU BERKAITAN \\ ISSN 2442-5729 (print) || ISSN 2598-2559 (online) \\ http://jurnal.umsu.ac.id/index.php/almarshad \\ DOI: //doi.org/10.30596/jam.v7i1.6404 || Vol. 7, No. 1 Juni 2021}

Berbeda dengan bulan yang berbasis Matahari. Untuk mengetahuinya, harus didasarkan pada pemikiran dan perhitungan terhadap peredaran Matahari. ${ }^{34}$

Penjelasan serupa dengan tafsir Sayyid Tantawi juga ditemukan dalam karya Wahbah al-Zuhaili dalam al-Tafsir al-Munir. Al-Zuhaili menyatakan bahwa menentukan waktu dengan bulan qamariyah dan tahun qamariyah itu mudah dalam perhitungannya dan sesuai dengan kondisi bangsa Arab. Adapun yang berbeda dengan al-Zuhaili bahwa ia juga menyebutkan alasan di balik disebut hilal, yaitu karena zuhur (tampaknya) bulan setelah khifaihi (tidak tampaknya bulan. $)^{35}$

Kajian tafsir ayat tentang hilal juga termaktub di kitab para mufassir Indonesia. Beberapa di antaranya adalah kitab tafsir alMisbah, tafsir al-Azhar, tafsir al-Ibriz, tafsir kementerian Agama RI, dan tafsir ilmi Kementerian Agama RI. Dalam Tafsir alMisbah, misalnya, sebelum menjelaskan hilal itu sendiri, Quraish Syihab menjelaskan fenomena astronomi bahwaBulan memantulkan sinar Matahari ke Bumi melalui permukaannya yang tampak dan terang hingga terbitlah sabit.

Pada paruh pertama, bulan berada

\footnotetext{
34 Sayyid Tantawi, Al-Tafsir Al-Wasit Li AlTantawi (Kairo: Dar Nahdah Misr, 1997).

${ }^{35}$ Wahbah al-Zuhaili, Al-Tafsir Al-Munir, Juz 1 (Damaskus: Dar al-Fikr al-Muashir, 1418).
}

pada posisi di antara matahari dan bumi, bulan itu menyusut yang berarti muncul bulan sabit baru. Ketika berada di arah berhadapan dengan matahari, di mana bumi berada di tengah, akan tampak bulan purnama Kemudian purnama itu kembali mengecil sedikit demi sedikit sampai ke paruh kedua, sehingga sempurnalah satu bulan Qamariyah selama 29,5309 hari.

Atas dasar fenomena ini dapat ditentukan penanggalan Arab, yaitu sejak munculnya bulan sabit hingga bulan tampak sempurna sinarnya. Bila bulan sabit tampak seperti garis tipis di ufuk barat, kemudian tenggelam beberapa detik setelah tenggelamnya matahari, ketika itu dapat terjadi rukyat terhadap bulan. Dengan cara inidapat ditentukan perhitungan awal bulan, begitu juga dengan permulaan dan akhir masa pelaksanaan ibadah haji. ${ }^{36}$

Apa yang diutarakan Habib Quraisy Syihab di atas mengisyaratkan perlunya fenomena kemunculan hilal yang disertai penampakannya agar dapat dijadikan tanda masuknya awal bulan. Pernyataannya juga mengindikasikan keterkaitan erat antara penampakan hilal dengan luasnya area bulan yang memantulkan sinar Matahari yang datang kepadanya.Hal ini bisa menjadi salah

${ }^{36}$ M. Quraish Syihab, Tafsir Al-Misbah: Pesan, Kesan, Dan Keserasian Al-Quran, Jilid 1 (Jakarta: LenteraHati, 2002). 


\section{AL-MARSHAD: JURNAL ASTRONOMI ISLAM DAN ILMU-ILMU BERKAITAN \\ ISSN 2442-5729 (print) || ISSN 2598-2559 (online) \\ http://jurnal.umsu.ac.id/index.php/almarshad \\ DOI: //doi.org/10.30596/jam.v7i1.6404 || Vol. 7, No. 1 Juni 2021}

satu pertimbangan dalam penentuan kriteria hilal sebagai penanda awal Bulan.

Lebih jelas lagi tentang hilal ini bisa kita lihat dalam penjelasan di kitab tafsir tahlili Kementerian Agama RI. Dalam tafsir ini dijelaskan bahwa bulan sebagai satelit Bumi berukuran sekitar 1/4 dari ukuran Bumi. Ia beredar mengelilingi bumi pada jarak ratarata 384.400 kilometer di bawah tarikan gaya gravitasi bumi. Akibat peredaran inilah bulan mengalami fase-fase, di antaranya fase bulan sabit,bulan separuh, bulan purnama, bulan baru dan bulan mati. Ketika bulan berada di antara bumi dan matahari, sisinya yang gelap menghadap ke bumi sehingga bulan tidak terlihat oleh kita yang di Bumi.

Bulan sabit terjadi antara fase bulan baru ke fase bulan separuh pertama (minggu pertama sebelum bulan purnama) dan antara fase bulan separuh kedua (minggu keempat, setelah bulan purnama) menuju fase bulan mati. Pada kedua fase bulan sabit, hilal Nampak seperti benang yang bisa dilihat di langit barat sesudah matahari tenggelam. ${ }^{37}$

Di buku tafsir ilminya, Kementerian Agama menegaskan bahwa Fase-fase bulan tersebut memiliki kejelasan dalam hal perubahannya. Perubahan yang jelas dari hari ke hari tersebut menyebabkan bulan dijadikan

37 Kementerian Agama RI, Al-Quran Dan Tafsirnya, Jilid 1 (Jakarta: PT. Sinergi Pustaka Indonesia, 2012). penentu waktu yang baik. Untuk masalah pemulaan awal bulan, hilal atau bulan sabit pertama yang bisa diamati digunakan sebagai acuan penentuannya.

\section{Karakteristik kejelasan perubahan} pada fase-fase bulan ini kemudian menjadi salaf satu faktor kemudahan dalam menentukan waktu. Hal ini karena semua orang bisa melakukan pengamatan dan menentukan waktu dengan mudah melalui hasil pengamatan fase bulan tersebut. Faktor kemudahan inilah yang juga dikedepankan dalam penentuan awal bulan dengan acuan hilal karena Allah SWT tidak menghendaki kesulitan terhadap hamba-Nya.

Sensasi ketidakmudahan dalam penentuan awal bulan dengan acuan hilal dalam perkembangannya saat ini bukan dari aspek teknis ilmiah. Sebab sebenarnya penentuannya memang mudah karena merupakan bagian ilmu eksakta dan fenomena astronomis yang bisa teramati. Ketidakmudahannnya terjadi karena dalam penerapannya di masyarakat menyangkut faktor lain seperti perbedaan mazhab hukum, perbedaan mat'la' dan kepercayaan kepada pemimpin umat yang tidak tunggal. ${ }^{38}$

Beberapa penjelasan dari kitab-kitab tafsir di atas banyak memberikan informasi

38 Kementerian Agama RI, Tafsir Ilmi: Penciptaan Jagat Raya Dalam Perspektif Al-Quran Dan Sains (Jakarta: PT Sinergi Pustaka Indonesia, 2012). 


\section{AL-MARSHAD: JURNAL ASTRONOMI ISLAM DAN ILMU-ILMU BERKAITAN \\ ISSN 2442-5729 (print) || ISSN 2598-2559 (online) \\ http://jurnal.umsu.ac.id/index.php/almarshad \\ DOI: //doi.org/10.30596/jam.v7i1.6404 || Vol. 7, No. 1 Juni 2021}

penting terkait karakteristik hilal yang digunakan sebagai penentu awal bulan. Berikut Tabel 3. karakteristik hilal tersebut:

Tabel 3. Karakteristik Hilal Perspektif Tafsir Ulama Kontemporer

\begin{tabular}{|c|c|c|c|}
\hline $\begin{array}{l}\mathbf{N} \\
\mathbf{0}\end{array}$ & Kriteria & $\begin{array}{l}\text { Karakteris } \\
\text { tik }\end{array}$ & $\begin{array}{l}\text { Keteranga } \\
\text { n }\end{array}$ \\
\hline 1 & Bentuk & $\begin{array}{ll}\text { - } & \text { Garis } \\
\text { tipis, } \\
\text { - } \quad \text { Tampak } \\
\text { Lembut } \\
\text { Seperti } \\
\text { benang }\end{array}$ & $\begin{array}{l}\text { Berdasarka } \\
\mathrm{n} \quad \text { luas } \\
\text { permukaan } \\
\text { bulan yang } \\
\text { terkena } \\
\text { sinar } \\
\text { matahari }\end{array}$ \\
\hline 2 & Fase & $\begin{array}{l}\text { - Antara } \\
\text { fase } \\
\text { bulan } \\
\text { baru ke } \\
\text { fase } \\
\text { bulan } \\
\text { separuh } \\
\text { pertama } \\
\text { - Fase } \\
\text { bulan } \\
\text { sabit } \\
\end{array}$ & $\begin{array}{l}\text { Kejelasan } \\
\text { fase } \\
\text { memberika } \\
\mathrm{n} \\
\text { kemudaha } \\
\mathrm{n} \text { kepada } \\
\text { manusia } \\
\text { dalam } \\
\text { penentuan } \\
\text { waktu }\end{array}$ \\
\hline 3 & $\begin{array}{l}\text { Ketampak } \\
\text { an }\end{array}$ & $\begin{array}{l}\text { Zuhur } \\
\text { ba'da } \\
\text { khifaihi } \\
\text { - } \quad \text { Tampak } \\
\text { dan bisa } \\
\text { dilihat }\end{array}$ & $\begin{array}{l}\text { keterkaitan } \\
\text { erat antara } \\
\text { penampak } \\
\text { an hilal } \\
\text { dengan } \\
\text { luasnya } \\
\text { area bulan } \\
\text { yang } \\
\text { memantulk } \\
\text { an sinar } \\
\text { Matahari } \\
\text { yang } \\
\text { datang } \\
\text { kepadanya }\end{array}$ \\
\hline 4 & Waktu & $\begin{array}{l}\text { di } 2 \text { malam } \\
\text { pertama }\end{array}$ & - \\
\hline 5 & Tempat & $\begin{array}{ll}\text { di } & \text { ufuk } \\
\text { barat }\end{array}$ & - \\
\hline
\end{tabular}

Berdasarkan Tabel 3. di atas, karakteristik hilal dapat dideskripsikan sebagai bagian bulan yang tampak (zuhur) tipis seperti benang pada 2 malam pertama setelah ketidaktampakannya (khifaih) pada fase bulan baru (new moon) di ufuk langit sebelah Barat setelah terbenam Matahari. Penampakan ketipisan hilal sesuai dengan luas area Bulan yang memantulkan sinar Matahari ketika diamati dari Bumi.Indikator ketampakan (zuhur) hilal ini adalah fenomena yang benar-benar jelas ketampakannya agar diperoleh kejelasan fase untuk memberikan kemudahan kepada manusia dalam penentuan waktu.

\section{Upaya Kompromisasi Substantif Makna Hilal}

Pada bagian ini, penulis berupaya mencari substansi makna hilal yang dijelaskan oleh para mufassir dari masa salaf, khalaf, hingga kontemporer. Beberapa temuan substansi tersebut kemudian saling dikompromikan sehingga ditemukan substansi universal makna hilal. Substansi universal ini bisa menjadi substansi yang mutlak harus ada pada semua tawaran kriteria hilal. Ia juga menjadi acuan dalam menentukan aspek-aspek terkait kriteria hilal seperti ketinggian, elongasi, umur bulan, dan mukus hilal, dan sebagainya.

Berdasarkan deskripsi hilal dari ketiga perspektif tafsir di atas, dapat dirumuskan 
persamaan dan perbedaannya. Persamaan yang diperoleh diasumsikan menjadi hakikat substantif hilal, sedangkan perbedaannya dianalisis dari aspek keniscayaannya untuk bisa ditambahkan dalam substansi universal hilal tersebut. Aspek keniscayaan tersebut dikaji dalam perspektif prinsip-prinsip hukum Islam, yaitu prinsip meniadakan kepicikan dan tidak memberatkan (adam alharaj), menyedikitkan beban (taqlil al-taklif), ditetapkan secara bertahap (tadrij), memperhatikan kemaslahatan manusia, dan meuwujudkan keadilan yang merata. Berikut Tabel 4. persamaan dan perbedaan hilal dalam ketiga perspektif tafsir tersebut:

Tabel 4. Perbandingan Karakteristik Hilal Perspektif Tafsir Ulama Salaf, Khalaf, dan kontemporer

\begin{tabular}{|c|c|c|c|c|}
\hline $\begin{array}{l}\mathbf{N} \\
\mathbf{0}\end{array}$ & $\begin{array}{l}\text { Aspe } \\
\text { k }\end{array}$ & $\begin{array}{l}\text { Tafsir } \\
\text { Ulam } \\
\text { a } \\
\text { Salaf }\end{array}$ & $\begin{array}{c}\text { Tafsir } \\
\text { Ulama } \\
\text { Khalaf }\end{array}$ & $\begin{array}{c}\text { Tafsir } \\
\text { Ulama } \\
\text { Kontem } \\
\text { porer }\end{array}$ \\
\hline 1 & $\begin{array}{l}\text { Bent } \\
\text { uk }\end{array}$ & $\begin{array}{l}\text { Misla } \\
\text { al- } \\
\text { khait }\end{array}$ & $\begin{array}{l}\text { Misla } \\
\text { al-khait } \\
\text { daqiqa } \\
n\end{array}$ & $\begin{array}{l}\text { Garis } \\
\text { tipis, } \\
\text { Lembut } \\
\text { Seperti } \\
\text { benang }\end{array}$ \\
\hline 2 & $\begin{array}{l}\text { Keta } \\
\text { mpak } \\
\text { an }\end{array}$ & $Y a b d u$ & $\begin{array}{l}\text { Awwalu } \\
\text { Ghurra } \\
\text { hal- } \\
\text { Qamar } \\
\text { Yabdu/ } \\
\text { Yura, } \\
\text { Fa } \\
\text { Yattali, } \\
u\end{array}$ & $\begin{array}{l}\text { Zuhur } \\
\text { ba'da } \\
\text { khifaihi, } \\
\text { tergantun } \\
\text { g luas } \\
\text { area } \\
\text { bulan } \\
\text { yang } \\
\text { terkena } \\
\text { sinar } \\
\text { matahari }\end{array}$ \\
\hline
\end{tabular}

\begin{tabular}{|c|c|c|c|c|}
\hline 3 & Fase & - & $\begin{array}{l}\text { Sirarba } \\
\text { 'daMih } \\
\text { aq }\end{array}$ & $\begin{array}{l}\text { Antara } \\
\text { fase } \\
\text { bulan } \\
\text { baru ke } \\
\text { fase } \\
\text { bulan } \\
\text { separuh } \\
\text { pertama }\end{array}$ \\
\hline 4 & $\begin{array}{l}\text { Wakt } \\
\mathrm{u}\end{array}$ & - & $\begin{array}{l}2 \\
\text { malam } \\
\text { pertam } \\
a \\
\end{array}$ & $\begin{array}{l}2 \text { malam } \\
\text { pertama }\end{array}$ \\
\hline 5 & $\begin{array}{l}\text { Temp } \\
\text { at }\end{array}$ & - & - & $\begin{array}{l}\text { di ufuk } \\
\text { barat }\end{array}$ \\
\hline 6 & $\begin{array}{l}\text { Kejel } \\
\text { asan }\end{array}$ & - & - & $\begin{array}{l}\text { Kejelasa } \\
\mathrm{n} \text { fase } \\
\text { memberi } \\
\text { kan } \\
\text { kemudah } \\
\text { an } \\
\text { kepada } \\
\text { manusia } \\
\text { dalam } \\
\text { penentua } \\
\text { n waktu }\end{array}$ \\
\hline
\end{tabular}

Berdasarkan Tabel 4. di atas, dapat dipahami bahwa karakteristik bentuk hilal yang menjadi kesepakatan ketiga perspektif tafsir adalah daqiqan misl al-khait, yaitu "lembut seperti benang". Kriteria Ini bisa menjadi salah satu karakteristik substantif hilal dalam pandangan ulama tafsir karena tidak ada satu pun yang berpendapat selain itu.

Pada aspek ketampakan, hilal merupakan Ghurrah al-Qamar yang yabdu, yattali'u, yura, dan zuhur. Keempat pilihan ini jika dikompromikan maka akan bermuara pada pernyataan bahwa hilal harus jelas 


\section{AL-MARSHAD: JURNAL ASTRONOMI ISLAM DAN ILMU-ILMU BERKAITAN \\ ISSN 2442-5729 (print) || ISSN 2598-2559 (online) \\ http://jurnal.umsu.ac.id/index.php/almarshad \\ DOI: //doi.org/10.30596/jam.v7i1.6404 || Vol. 7, No. 1 Juni 2021}

(zuhur) ketampakannya (yabdu) dan bisadiamati (yura) agar dapatdikatakan terbit (yattali'u). Jika disederhanakan, maka karakteristik substantif hilal berikutnya adalah badawah wa zuhur, yaitu "tampak".

Dalam hal fase, hilal berada di fase sirar yang berada di antara fase bulan baru (mihaq) dan fase bulan separuh (tarbi'). Pada fase mihaq, hilal pada posisi ketika tidak ada cahaya yang dipantulkan atau sangat tipisnya cahaya yang dipantulkan sehingga ia belum mencapai pada batas penampakan yang lembut sekalipun. Kemudian pada fase sirar, hilal mulai muncul dan teramati dalam keadaan penampakannya yang samar-samar (sirar) karena bentuknya yang tipis dan lembut seperti benang.

Waktu kemunculan hilal adalah pada 2 malam pertama. Ini menunjukkan bahwa hilal merupakan fenomena penampakan astronomis yang hanya terjadi di malam hari, bukan di siang hari. Yang di maksud malama dalah waktu yang dimulai sejak terbenam matahari hingga terbitnya fajar. Sedangkan tempat terbitnya hilal ada pada ufuk langit sebelah barat.

Adapun yang dimaksud dengan aspek "kejelasan" adalah tampak jelasnya perubahan bentuk qamar (bulan) dari satu fase ke fase yang lain. Kejelasan ini memberikan karakteristik tambahan pada substansi hilal, yaitu kemudahan bagi manusia dalam menentukan waktu-waktu dalam kehidupan mereka. Hal ini berimplikasi kepada penguatan karakteristik badawah pada hilal. Perubahan yang dipakai dan direkomendasikan adalah perubahan yang jelas, sebab perubahan yang belum jelas bisa memberikan kesulitan bagi manusia dalam penentuan waktu.

$$
\text { Argumentasi normatif-filosofis }
$$
dipilihnya aspek kejelasan perubahan bentuk qamar agar memberikan kemudahan bagi manusia adalah salah satu prinsip dasar dari ajaran Islam, yaitu 'adam al-haraj, tidak adanya kesulitan. Dipaksakannya kriteria hilal yang masih mengindikasikan perubahan bentuk yang belum jelas akan tidak sesuai dengan prinsipdasar ajaran Islam ini dan memberikan kesulitan bagi manusia.

Dalam Tabel di atas juga dapat diketahui bahwa pada fase tafsir kontemporer aspek tentang hilal yang dibahas semakin banyak dibanding pada fase sebelumnya. Hal ini disebabkan antara lain bahwa tafsir kontemporer merupakan perpaduan antara tafsir bi al-Ma'sur dan tafsir bi al-Ra'yi. Metode yang adalah metode maudhui dan kontekstual.

Metode kontekstual memiliki makna penting antara lain: a. Upaya pemaknaan dalam rangka mengantisipasi persoalan yang dewasa ini yang umumnya mendesak. Sehingga arti kontekstual identik dengan 


\section{AL-MARSHAD: JURNAL ASTRONOMI ISLAM DAN ILMU-ILMU BERKAITAN \\ ISSN 2442-5729 (print) || ISSN 2598-2559 (online) \\ http://jurnal.umsu.ac.id/index.php/almarshad \\ DOI: //doi.org/10.30596/jam.v7i1.6404 || Vol. 7, No. 1 Juni 2021}

situasional. b. Pemaknaan yang melihat keterkaitan masa lalu, dan masa mendatang; dimana sesuatu akan dilihat dari sudut makna historis dulu, makna fungsional saat ini, dan memprediksi makna (yang dianggap relevan) dikemudian hari. c. Mendudukan antara yang sentral dan yang periferi, dalam arti yang sentral adalah teks al qur`an, dan yang periferi adalah terapannya. Selain itu juga mendudukan al qur`an sebagai sentral moralitas.

Di samping itu, salah satu corak tafsir yang berkembang pada masa kontemporer adalah corak tafsir ilmi. Dalam corak penafsiran ini seorang mufassir dalam memahami ayat-ayat al-Quran cenderung menyelaraskan antara teori ilmiah atau aspek metafisika alam dalam ayat al-Quran. AlQuran yang bersifat universal telah memberikan gambaran seluas-luasnya tentang fenomena alam semesta, yang ternyata setelah dicocokkan sangat berkesesuaian dengan teori ilmu pengetahuan yang dimiliki manusia saat ini. ${ }^{39}$

Fase kontemporer ini pada abad 19 dan 20. Pada abad ini ilmu astronomi sudah semakin maju, juga dengan kajian tentang hilal. Di antara tokoh pada masa ini adalah Muhammad Ilyas (1981) dengan kriteria

39 Muhammad Amin, 'Kontribusi Tafsir Kontemporer Dalam Menjawab Persoalan Ummat', Substantia, 15.1 (2013), 6. visibillitas hilalnya yang memperbaiki gabungan kriteria fisis dan empiris F. Bruin.

\section{Pembahasan}

\section{Hakikat Hilal Perspektif Tafsir al-Quran}

Berdasarkan upaya kompromisasi karakteristik substantif hilal di atas, dapat dipahami hakikat hilal perspektif tafsir alQuran. Ada beberapa aspek yang meliputi hakikat hilal tersebut, yaitu aspek bentuk, ketampakan, fase, waktu, tempat, dan kejelasan perubahan bentuk. Hilal yang dikehendaki tafsir al-Quran harus memenuhi karakteristik yang dijelaskan para mufassir pada ke enam aspek tersebut. Berikut bagan ke enam aspek hakikat hilal tersebut:

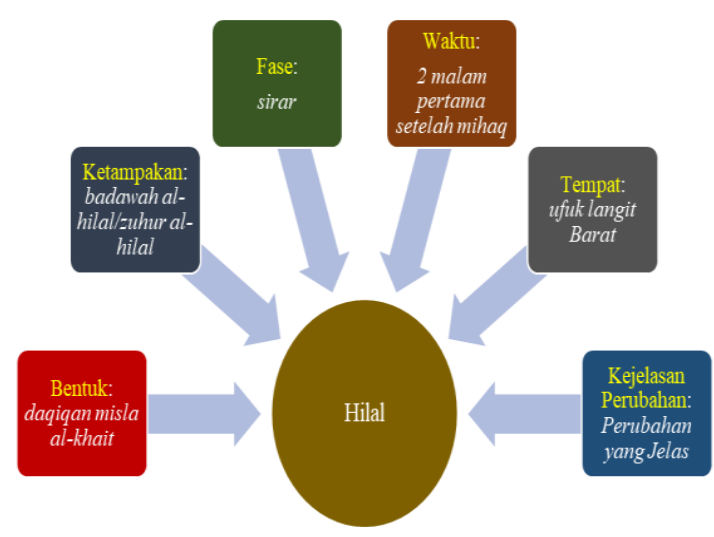

Bagan di atas menginformasikan bahwa hakikat hilal dalam perspektif tafsir alQuran adalah bulan sabit yang tampak dari permukaan Bumi dengan enam karakteristik, yaitu bentuknya lembut seperti benang, fenomena ketampakannya dapat teramati 


\section{AL-MARSHAD: JURNAL ASTRONOMI ISLAM DAN ILMU-ILMU BERKAITAN \\ ISSN 2442-5729 (print) || ISSN 2598-2559 (online) \\ http://jurnal.umsu.ac.id/index.php/almarshad \\ DOI: //doi.org/10.30596/jam.v7i1.6404 || Vol. 7, No. 1 Juni 2021}

(badawah wa zuhur), berada pada fase sirar pada 2 malam pertama setelah fase mihaq di ufuk langit sebelah Barat, dengan perubahan fase yang jelas sehingga memberikan kemudahan bagi manusia dalam penentuan waktu. Kondisi bulan yang tidak sesuai dengan keenam karakteristik di atas, dalam perspektif tafsir al-Quran tidak disebut dengan hilal.

Dari ke enam aspek di atas, ada satu aspek penting yang belum dimunculkan dalam diskusi-diskusi falakiyah. Aspek tersebut adalah badawah al-hilal atau zuhur al-hilal, yang berarti tampaknya fenomena hilal yang bisa teramati dari muka Bumi. Badawah al-hilal atau zuhur al-hilal ini berbeda dengan wujud al-hilal dalam hal ketidak perduliannya akan tampak tidaknya hilal di saat tingginya sudah di atas ufuk. Dengan rukyah al-hilal, ia tidak sepakat dengan tidak dianggapnya masuk awal bulan Hijriyah jika hilal tidak bisa dilihat pada saat cuaca tidak normal, sedangkan berdasarkan perhitungan ia bisa teramati dalam cuaca cerah.

Kriteria badawah al-hilal atau zuhur al-hilal ini lebih dekat dengan kriteria imkan al-rukyah yang berusaha menyatukan wujud al-hilal dan rukyah al-hilal. Keduanya sepakat bahwa ketinggian hilal di atas ufuk yang belum memenuhi syarat untuk "ketampakan hilal" dari muka Bumi belum bisa diterima, dan ketidaktampakan hilal karena terhalangnya pandangan pengamat oleh ketidaknormalan cuaca tidak menghilangkan sifat "ketampakan hilal" jika memang sudah memenuhi syarat untuk tampak.

Aspek penting berikutnya yang juga belum disentuh dalam diskusi ijtihad falakiyah adalah aspek kejelasan perubahan fase hilal sehingga memberikan kemudahan bagi manusia untuk menggunakannya dalam penentuan waktu. Tawaran kriteria hilal yang tidak mencerminkan kejelasan perubahan fase hilal sehingga memberikan kesulitan bagi manusia tidak direkomendasikan untuk digunakan dalam penentuan waktu.

\section{Penutup}

Berdasarkan diskusi dalam paparan di atas, dapat disimpulkan jawaban dari kedua pertanyaan dalam penelitian ini. Pertama, hilal yang diinformasikan dalam ayat-ayat berkaitan dengannya dijelaskan oleh para mufassir dalam enam aspek atau karakteristik, yaitu aspek bentuk, ketampakan, fase, waktu, tempat, dan kejelasan perubahan.

Kesimpulan kedua berkaitan dengan hakikat hilal perspektif tafsir al-Quran. Hilal perspektif tafsir al-Quran adalah hilal yang bentuknya lembut seperti benang, fenomena 


\section{AL-MARSHAD: JURNAL ASTRONOMI ISLAM DAN ILMU-ILMU BERKAITAN \\ ISSN 2442-5729 (print) || ISSN 2598-2559 (online) \\ http://jurnal.umsu.ac.id/index.php/almarshad \\ DOI: //doi.org/10.30596/jam.v7i1.6404 || Vol. 7, No. 1 Juni 2021}

ketampakannya dapat teramati (badawah alhilal atau zuhur al-hilal), berada pada fase sirar, pada 2 malam pertama setelah fase mihaq, di ufuk langit sebelah Barat, dengan perubahan fase yang jelas sehingga memberikan kemudahan bagi manusia dalam penentuan waktu.

\section{Daftar Pustaka}

Abd al-Razzaq al-San'ani, Tafsir Abd AlRazzaq (Beirut: Dar al-Kutub alIlmiyyah, 1419)

Abu al-Hajjaj Mujahid Ibn Jabr, Tafsir Mujahid (Mesir: Dar al-Fikr al-Islami, 1989)

Abu al-Hasan al-Wahidy, Al-Tafsir Al-Basit

(Arab Saudi: Jami’ah Imam Muhammad Ibn Saud al-Islamiyah, 1430)

Abu al-Hasan Ali al-Mawawrdi, Al-Nukt Wa Al-Uyun: Tafsir Al-Mawardi (Beirut: Dar al-Kutub al-Ilmiyyah)

Abu al-Hasan Muqatil ibn Sulaiman, Tafsir Muqatil Ibn Sulaiman (Beirut: Dar Ihya al-Turas, 1423)

Abu al-Hasan Muqatil Ibn Sulaiman, Tafsir Muqatil Ibn Sulaiman (Beirut: Dar Ihya al-Turas, 1423)

Abu al-Lais al-Samarqandi, Bahr Al-Ulum Abu al-Mudaffar al-Sam'any, Tafsir AlQuran (Riyad: Dar al-Watan, 1997) Abu al-Qasim Burhanuddin al-Karmany, Garaib Al-Tafsir Wa 'Ajaib Al-Ta'Wil
(Beirut: Dar al-Qiblah li al-Saqafah)

Abu Ishaq Ahmad Ibn Ibrahim al-Sa'labi, Al-

Kasyf Wa Al-Bayan 'An Tafsir Al-Quran

(Arab Saudi: Dar al-Tafsir, 2015)

Abu Mansur al-Maturidi, Tafsir Al-Maturidi:

Ta'wilat Ahli Al-Sunnah (Beirut: Dar alKutub al-Ilmiyyah, 2005)

Ahmad ibn Mustafa al-Maragi, Tafsir AlMaragi (Mesir: Matba'ah Mustafa alHalabi, 1946)

Al-Fairuzzabadi, Tanwir Al-MiqbasMin Tafsir Ibn Abbas (Beirut: Dar al-Kutub al-Ilmiyyah)

Al-Qism al-Ilmi Bi Muassasah al-Durar alSaniyyah, Al-Tafsir Al-Muharrar Li AlQuran Al-Karim (Arab Saudi: al-Durar al-Saniyyah, 2015)

Al-Syafii, Imam, Tafsir Al-Imam Al-Syafi'i

(Arab Saudi: Dar al-Tadammuriyyah, 2006)

Al-Syay'rawy, Tafsir Al-Sya'rawy (Mesir:

Akhbar al-Yaum, 1997)

Dalhari, 'Tafsir Modern Di Timur Tengah Abad 19 Dan 20', Mutawatir: Jurnal Keilmuan Tafsir Dan Hadis, 3.1 (2013), 66-67

Fahmi Fatwa Rosyadi Satria Hamdani. Alhamuddin Alhamuddin dan Putra Bagus Mochammad, 'Al-Hilal Fi AlQuran: Tasmiyah Al-Hilal Wa Tatawwuruha Ind Ulama Al-Tafsir AlMutaqaddimin Wa Al-Mu'ashirin Ala 


\section{AL-MARSHAD: JURNAL ASTRONOMI ISLAM DAN ILMU-ILMU BERKAITAN \\ ISSN 2442-5729 (print) || ISSN 2598-2559 (online) \\ http://jurnal.umsu.ac.id/index.php/almarshad \\ DOI: //doi.org/10.30596/jam.v7i1.6404 || Vol. 7, No. 1 Juni 2021}

Wajh Al-Maudlu'i', Jurnal Tsaqafah:

Jurnal Peradaban Islam, 12.2 (2016), 409-24

Fakhruddin al-Razy, Mafatih Al-Gaib

(Beirut: Dar Ihya al-Turas, 1420)

Ibn Abi Hatim al-Razi, Tafsir Al-Quran AlAdim Li Ibn Hatim (Arab Saudi:

Maktabah Nazar Mustafa al-Baz, 1419)

Ibn Asyur, Al-Tahrir Wa Al-Tanwir (Tunis:

al-Dar al-Tunisiah, 1984)

Ibn Jarir al-Tabari, Jami' Al-Bayan Fi Ta'wil

Al-Quran (Beirut: Muassasah al-

Risalah, 2000)

Ibn Makhluf al-Sa'alabi, Al-Jawahir Al-

Hissan Fi Tafsir Al-Quran

Kementerian Agama RI, Al-Quran Dan

Tafsirnya, Jilid 1 (Jakarta: PT. Sinergi

Pustaka Indonesia, 2012)

—

Dalam Perspektif Al-Quran Dan Sains

(Jakarta: PT Sinergi Pustaka Indonesia, 2012)

Khazanah, Uswatun, Penafsiran Hilal

Menurut Qurthubi Dan Tantawi

Jauhari, Skripsi (UIN Sunan Gunung

Jati, 2018)

M. Quraish Syihab, Tafsir Al-Misbah: Pesan,

Kesan, Dan Keserasian Al-Quran, Jilid

1 (Jakarta: LenteraHati, 2002)

Muhammad Amin, 'Kontribusi Tafsir

Kontemporer Dalam Menjawab

Persoalan Ummat', Jurnal Substantia,
15.1 (2013), 4

-, 'Kontribusi Tafsir Kontemporer

Dalam Menjawab Persoalan Ummat',

Substantia, 15.1 (2013), 6

Muhammad Ibn Jarir Al-Tabari, Jami' Al-

Bayan Fi Ta'wil Al-Quran (Beirut:

Muassasah al-Risalah, 2000)

Muhammad, Yuchbibun Nury, Tafsir Ayat-

Ayat Hilal Perspektif Kemenag RI Dan

LIPI, Diploma th (Institut Pesantren KH.

Abdul Chalim, 2020)

Raisal, Abu Yazid, 'Berbagai Konsep Hilal Di Indonesia', Al-Marshad, 4.2 (2018), $151-53$

Sayyid Tantawi, Al-Tafsir Al-Wasit Li Al-

Tantawi (Kairo: Dar Nahdah Misr, 1997)

Wahbah al-Zuhaili, Al-Tafsir Al-Munir, Juz 1

(Damaskus: Dar al-Fikr al-Muashir, 1418)

Yahya Ibn Salam, Tafsir Yahya Ibn Salam (Beirut: Dar al-Kutub al-'ilmiyyah, 2004)

Zaman, Qamarus, 'Memahami Makna Hilal Menurut Tafsir Al-Quran Dan Sains', Universum, 9.1 (2015) 